\title{
PENGARUH EFISIENSI, EFEKTIVITAS, DAN LEVERAGE TERHADAP KINERJA KEUANGAN PERUSAHAAN PUBLIK BISNIS RITEL
}

\begin{abstract}
Anathania Lendrawati dan Maswar Abdi
Program Studi Manajemen Fakultas Ekonomi dan Bisnis Universitas Tarumanagara, Jakarta E-mail: anathania.115170047@stu.untar.ac.id

Abstract: The purpose of this study was to determine how the effect of operational efficiency, marketing effectiveness, and financial leverage on the financial performance of a public retail business. The population in this study are retail sub-sector companies listed on the Indonesia Stock Exchange (IDX) in the 2016-2020 period. This study uses multiple linear regression analysis techniques using Eviews 11 software. The results of this study indicate that (1) operational efficiency has a negative and significant effect on financial performance, (2) marketing effectiveness has a positive and significant effect on financial performance, (3)leverage finance has a negative and significant effect on financial performance.
\end{abstract}

Keywords: operational efficiency, marketing effectiveness, financial leverage, financial performance

\begin{abstract}
Abstrak: Tujuan penelitian ini adalah untuk mengetahui bagaimana pengaruh efisiensi operasional, efektivitas pemasaran, dan leverage keuangan terhadap kinerja keuangan perusahaan publik bisnis ritel. Populasi dalam penelitian ini adalah perusahaan sub sektor ritel yang terdaftar di Bursa Efek Indonesia (BEI) pada periode 2016-2020. Penelitian ini menggunakan teknik analisis regresi linear berganda dengan menggunakan software Eviews 11. Hasil dari penelitian ini menunjukan bahwa (1) Efisiensi operasional berpengaruh negatif dan signifikan terhadap kinerja keuangan, (2) Efektivitas pemasaran berpengaruh positif dan signifikan terhadap kinerja keuangan, (3) Leverage keuangan berpengaruh negatif dan signifikan terhadap kinerja keuangan.
\end{abstract}

Kata Kunci: efisiensi operasional, efektivitas pemasaran, leverage keuangan, kinerja Keuangan

\section{LATAR BELAKANG}

Dalam beberapa tahun belakangan, industri ritel di Indonesia mendapat sorotan publik dimana masih terdapat beberapa perusahaan yang menunjukan pertumbuhan meskipun tidak sama seperti tahun-tahun sebelumnya. Pada kondisi saat ini perusahaan ritel sedang mengalami penurunan yang cukup drastis bahkan bisa sampai menutup gerai tokonya.

Pada umumnya, suatu perusahaan memiliki tujuan utama adalah memaksimalkan kekayaan bagi pemilik perusahaan (Horne \& Wachowicz, Jr, 2008, p. 3). Rasio keuangan yang umum digunakan untuk menilai kinerja keuangan dalam mencapai tujuan perusahaan tersebut adalah Return on Equity (ROE) yaitu Earning after Tax (EAT) dibagi Total Ekuitas. EAT merupakan tambahan kekayaan pemilik perusahaan yang berasal dari kegiatan operasional perusahaan, Dengan demikian, ROE ini mencerminkan prosentase peningkatan Nilai kekayaan pemilik (ekuitas) dalam satu periode pembukuan 
Dalam mengukur kinerja keuangan, perusahaan melakukan analisa berdasarkan pada laporan keuangan terutama laporan laba rugi dan neraca. Ada berbagai bentuk rasio keuangan yang disajikan dalam mengevaluasi kinerja keuangan, seperti Liquidity ratio, Debt ratio, Activity ratio, Profitability ratio dan Market ratio (Yohanes \& Abdi, 2020). Dari berbagai bentuk rasio, rasio profitabilitas dianggap dapat dijadikan sebagai alat pengukur kinerja keuangan (Brigham \& Ehrhardt, 2017). Keberhasilan kinerja keuangan pada suatu perusahaan dapat dilihat dari rasio profitabilitas yang dimiliki oleh perusahaan tersebut (Wahyuni, 2017).

Rasio profitabilitas merupakan suatu tolak ukur yang digunakan untuk mengukur kinerja perusahaan dalam menghasilkan laba, dimana rasio profitabilitas dapat memberikan gambaran tentang efektifitas manajemen perusahaan berdasarkan dari hasil pengembalian yang didapat dari penjualan dan investasi. Naik dan turunnya laba yang diperoleh akan mempengaruhi rasio profitabilitas, karena dapat mengakibatkan pada keputusan investor saat menanam modal pada suatu perusahaan. Hal ini ditunjukan oleh semakin naiknya laba yang diperoleh, maka return yang didapat akan semakin besar.

Perusahaan perdagangan eceran (retail trade) merupakan salah satu sub sektor yang sudah mendominasi pada kehidupan masyarakat Indonesia dan salah satu sub sektor yang sangat popular secara turun-temurun, dimana hal ini ditunjukan dengan tersebar luasnya warung ataupun toko kelontong diseluruh daerah mulai dari pedesaan hingga perkotaan. Pertumbuhan dan perkembangan industri perdagangan eceran ini memiliki prospek yang baik dan perkembangannya pun sangat cepat seiring dengan pertambahan laju penduduk di Indonesia. Sub sektor industri ini semakin popular semenjak masuknya retail modern di Indonesia, seperti Alfamart, Alfamidi, Indomaret, Carrefour, Hero supermarket, dan Hypermart (Nurviani, 2013).

Tabel 1. Return on Equity Perusahaan Publik Bisnis Ritel yang terdaftar di BEI periode 2016-2020 (dalam presentase).

\begin{tabular}{|c|c|}
\hline Tahun & ROE \\
\hline 2016 & 12,53 \\
\hline 2017 & 5,01 \\
\hline 2018 & 4,28 \\
\hline 2019 & $-0,72$ \\
\hline 2020 & $-32,09$ \\
\hline
\end{tabular}

Sumber: www.idx.com

Melalui tabel diatas, kita dapat melihat bahwa rata-rata ROE Perusahaan Publik Bisnis Ritel mulai dari tahun 2016 sampai tahun 2020 mengalami penuruan disetiap tahunnya dan penurunan yang paling drastis adalah pada tahun 2020. Ini merupakan hal yang sangat menarik untuk diteliti. Oleh sebab itu, penulis melalukan penelitian tentang sejauh mana pengaruh faktor yang membentuk ROE secara teoritis yaitu efisiensi operasional, efektivitas pemasaran, dan leverage keuangan terhadap perubahan ROE tersebut.

Tujuan akhir suatu perusahaan adalah meningkatkan nilai kekayaan pemilik, baik nilai buku ataupun nilai pasar. Secara akuntansi (nilai buku), kinerja keuangan dapat diukur dengan ROE karena ROE tersebut mencerminkan prosentase perubahan nilai Total Ekuitas (kekayaan pemilik) akibat perubahan Earning After Tax (EAT). 
Secara garis besar, konsep atau teori utama yang melandasi penelitian ini adalah $\mathrm{Du}$ Pont Analysis. Konsep Du Pont System diperkenalkan digunakan sejak tahun 1914 oleh perusahaan DuPont. Teori ini pertama kali membahas tentang berbagai faktor yang membentuk Return on Assets (ROA) secara bertahap.

Konsep Du Pont Analysis dikembangkan lagi oleh berbagai ahli dalam bidang keuangan. Pengembangan teori Du Pont yang terakhir memfokuskan perhatian pada ROE. Dalam hal ini, ROE dibentuk dan dipengaruhi oleh ROA dan Equity Multiplier. Selanjutnya ROA dibentuk dan dipengaruhi oleh Net Profit Margin (NPM) dan Total Asset Turnover (TATO).

Net Profit Margin merupakan presentase kelebihan penjualan diatas total beban yang dikeluarkan untuk mencapai penjualan tersebut. Rasio Total Beban terhadap Penjualan adalah mencerminkan tingkat efisiensi kegiatan operasional perusahaan dalam suatu periode pembukuan. Leverage keuangan dapat disajikan dengan rasio Debt to Total Assets atau Debt to Equity Ratio (DER). Equity Multiplier adalah rasio utang terhadap Total Asset dan Total Asset sama dengan Total Utang ditambah Total Ekuitas. Dengan demikian Equity multiplier = $1+$ DER.

Dalam penelitian ini, penulis hanya mengambil faktor utama yang membentuk dan mempengaruhi ROE menjadi variabel penelitian yaitu Rasio Effisiens Operasional, Effektifitas Pemasaran yang dicerminkan oleh TATO dan Leverage Keuangan yang dicerminkan oleh DER.

Net Profit Margin (NPM) merupakan rasio yang membandingkan laba bersih dengan penjualan, dimana bertujuan untuk mengetahui apakah suatu perusahaan telah efisien dalam menjalankan kinerjanya dan untuk melihat kemampuan perusahaan saat menghasilkan laba setelah pajak. Besar dan kecilnya rasio Net Profit Margin (NPM) pada setiap transaksi penjualan dipengaruhi oleh faktor laba bersih dan penjualan. Perusahaan akan semakin bagus dalam menghasilkan laba, jika rasio yang di peroleh semakin besar. Semakin tinggi rasio Net Profit Margin (NPM) maka kinerja perusahaan akan semakin baik dan dapat menggambarkan bahwa suatu perusahaan mampu untuk mengendalikan biaya produksinya.

Kinerja perusahaan dapat dilihat juga dari bagaimana pemasaran dalam suatu perusahaan yang dapat diukur dengan menggunakan rasio Total Asset Turnover (TATO), dimana rasio ini dapat menggambarkan bagaimana aktivitas perusahaan mengelola asset secara efektif agar dapat memperoleh pendapatan yang tinggi. Tingginya Total Asset Turnover (TATO) dapat menunjukan bahwa suatu perusahaan telah efisien dalam menggunakan asset saat melakukan penjualan. Sehingga semakin tinggi Total Asset Turnover (TATO) maka laba yang didapatkan juga akan semakin tinggi.

Selain dari sisi laba bersih dan perputaran asset, terdapat leverage yang dapat mempengaruhi kinerja pada suatu perusahaan yaitu leverage keuangan. Debt to Equity Ratio (DER) merupakan salah satu rasio keuangan yang menghitung total hutang dan total ekuitas yang perusahaan miliki. Jika hutang yang digunakan oleh perusahaan semakin kecil, maka bagi pemegang saham akan semakin lebih menguntungkan.

Dalam menentukan Return on Equity terdapat banyak faktor yang dapat mempengaruhi seperti yang telah diuraikan diatas yaitu Net Profit Margin, Total Asset Turnover, dan Leverage Keuangan. Suatu perusahaan agar dapat mempertahankan posisinya dalam persaingan, maka manajemen dalam suatu perusahaan harus memperhatikan dengan cermat setiap kebijakan yang akan diambil oleh perusahaan. 


\section{KAJIAN TEORI}

\section{Du Pont Analysis}

Menurut Weston dan Brigham dalam (Tarmizi \& Marlim, 2016) menjelaskan bahwa, pada tahun 1914 Du Pont Corporation yang mempelopori salah satu metode yang analisis keuangan perusahaan yang sampai saat ini dikenal dengan nama Analisis Du Pont, dimana "Analisis Du Pont System adalah analisa yang mencakup seluruh rasio aktivitas dan margin keuntungan atas penjualan untuk menunjukan bagaimana rasio ini mempengaruhi profitabilitas". Du Pont System merupakan suatu kerangka analisis yang menghubungkan berbagai macam rasio, yaitu menghubungkan antara Net Profit Margin (NPM) yang digunakan untuk mengukur profitabilitas dengan Total Asset Turnover (TATO) yang digunakan untuk mengetahui efisiensi dari suatu perusahaan dalam menggunakan asetnya untuk menghasilkan penjualan (Sugiono \& Untung, 2008, p. 81).

Analisis Du Pont bertujuan untuk menganalisis laporan keuangan dan untuk menilai kondisi kinerja suatu perusahaan. Kondisi keuangan sendiri dapat diukur dengan menggunakan pendekatan Du Pont Analysis. Dalam melakukan pengukuran, Du Pont Analysis ini lebih menekankan pada perhitungan komponen-komponen yang terdapat didalam laporan laba rugi (income statement) dan laporan neraca (balance sheet) pada suatu perusahaan (Prianto \& Amboningtyas, 2017). Hal ini didukung oleh Husnan \& Pudjiastuti (2012:80) yang menyatakan bahwa analisis Du Pont memusatkan analisis pada Return on Equity (ROE), yang dimana semakin tinggi Return on Equity (ROE) maka akan semakin baik tingkat pengembalian bagi pemilik ekuitas. Du Pont System adalah pemecahan dari Return on Equity (ROE) yang dibagi menjadi tiga bagian utama yaitu efisiensi operasional yang diproksikan dengan Net Profit Margin (NPM), efisiensi asset yang diproksikan dengan Total Asset Turnover (TATO) dan leverage keuangan yang diproksikan dengan equity multiplier (Ross, et al, 2006). Menurut Gitman dan Zutter (2012:85) Analisis Du Pont System adalah suatu system yang digunakan untuk membedah laporan keuangan perusahaan dan menilai kondisi keuangan perusahaan.

Menurut Gitman dan Zutter (2012:89) yang menyatakan bahwa Analisis Du Pont System merupakan suatu analisis yang menggabungkan antara laporan laba rugi dan neraca menjadi dua ukuran profitabilitas yaitu Return on Asset (ROA) yang biasa disebut dengan Return on Investment (ROI) yang menggambarkan kemampuan suatu perusahaan dalam menghasilkan laba dengan menggunakan asetnya serta Return on Equity (ROE) yang mengukur pengembalian yang diperoleh dari investasi pemegang saham pada suatu perusahaan. Du Pont System ini juga menunjukan hubungan antara Net Profit Margin (NPM), Total Asset Turnover (TATO) dan Return on Investment (ROI) (Kariyoto, 2017, p. 173). Dimana awalnya Du Pont System ini merupakan Return on Asset atau Return on Inverstment yang dihasilkan oleh perkalian antara net profit margin sebagai pengukur profitabilitas suatu perusahaan dalam melakukan penjualan dengan total asset turnover yang mengidentifikasikan seberapa efisiennya suatu perusahaan dalam menggunakan asetnya untuk menghasilkan penjualan (Wahyudiono, 2014, p. 92).

Penggunaan leverage keuangan mengubah Return on Asset (ROA) menjadi Return on Equity (ROE), dimana ROE dapat mencerminkan pengaruh leverage keuangan terhadap laba pemilik perusahaan. Menurut Wahyudiono (2014:91) mengatakan bahwa Equity Multiplier (EM) adalah salah satu rasio antara equity dan total asset. Perusahaan yang menggunakan pendanaan dalam jumlah besar dengan hutang akan memiliki Equity Multiplier (EM) yang tinggi. Oleh karena itu, semakin besar hutang pada suatu perusahaan dalam melakukan pendanaan maka equity multiplier akan semakin besar juga. Hal ini menunjukan bahwa ROE memiliki ketergantungan pada seberapa besarnya equity multiplier dan menunjukan besarnya hutang akan mempengaruhi ROE. 


\section{Kinerja Keuangan}

Menurut Blocher, dkk (2007:27) menyatakan bahwa kinerja keuangan merupakan suatu indikator yang dapat digunakan untuk mengukur keberhasilan suatu perusahaan dalam menghasilkan laba yang dapat memuaskan pemilik maupun pemegang saham. Kinerja keuangan merupakan hasil atau prestasi yang telah dicapai perusahaan dalam mengelola asetnya secara efektif dalam selama periode tertentu (Rudianto, 2013, p. 189). Didukung dengan pernyataan bahwa kinerja keuangan adalah suatu penentu dalam ukuran tertentu yang dapat digunakan untuk mengukur keberhasilan suatu organisasi atau perusahaan dalam menghasilkan laba (Sucipto, 2003). Oleh karena itu, hal ini sangat penting bagi setiap perusahaan dalam persaingan bisnis untuk mempertahankan keberlangsungan perusahaanya (Dewa, 2015).

\section{Analisis Laporan Keuangan}

Laporan keuangan merupakan suatu informasi yang dapat menggambarkan kondisi suatu perusahaan yang selanjutnya akan menjadi informasi yang menggambarkan tentang kinerja suatu perusahaan (Fahmi, 2011, p. 23). Laporan keuangan adalah suatu alat penguji perusahaan agar dapat mengetahui dimana posisi keuangan perusahaan tersebut dan memiliki peran dalam membantu berbagai pihak yang berkepentingan untuk membuat keputusan (Maruta, 2018). Pada dasarnya laporan keuangan merupakan hasil dari proses akuntansi yang dapat digunakan sebagai alat untuk mengkomunikasikan data keuangan maupun aktivitas suatu perusahaan kepada pihak yang berkepentingan (Herry, 2015, p. 3). Pentingnya suatu perusahaan memiliki laporan keuangan yang telah dianalisis, karena laporan keuangan dapat menggambarkan kondisi keuangan suatu perusahaan serta dapat memberikan informasi mengenai hasil yang perusahaan capai dan sebagai alat informasi posisi keuangan perusahaan serta hasil yang perusahaan sudah capai. Laporan keuangan yanh telah dianalisis berfungsi untuk memberikan informasi kepada pengambilan keputusan yaitu seperti pemberi pinjaman, manajemen dan investor (Sinha, 2012, p. 75).

\section{Return on Equity}

Return on Equity (ROE) adalah suatu rasio yang digunakan untuk mengukur laba bersih (net income) sesudah pajak dengan modal sendiri (Dewi, 2018). Return on Equity (ROE) adalah rasio antara laba sesudah pajak terhadap total ekuitas yang berasal dari setoran pemilik (Rumondang, dkk, 2012). Beberapa faktor yang mempengaruhi saat menentukan Return on Equity (ROE) dalam laporan keuangan antara lain Net Profit Margin (NPM) tentang keuntungan atas komponen-komponen penjualan, Total Asset Turnover (TATO) tentang efisiensi penggunaan aktiva, dan Equity Multiplier (EM) merupakan dari perbandingan antara total aktiva dengan modal equity (Kusmayadi, 2008). Maka rumus dari ROE sebagai berikut:

$$
\text { Return on Equity }=\frac{\text { Earning After Tax }}{\text { Total Equity }} \times 100 \%
$$

\section{Efisiensi Operasional}

Suatu perusahaan dapat dikatakan efisien jika dilihat dari saat perusahaan tersebut dapat menghasilkan output sebesar-besarnya dengan input sekecil-kecilnya. Efisiensi operasional pada suatu perusahaan hanya dapat tercapai apabila suatu perusahaan dapat mengendalikan seluruh biaya yang dikeluarkan untuk menghasilkan pendapatan ( Junaidi , 2018). Efisiensi operasional dapat menilai kemampuan suatu perusahaan dalam membayar kewajiban jangka pendek. Efisiensi operasional diproksikan dengan Expense to Sales (ETS). Maka rumus dari Expense to Sales sebagai berikut: 


$$
\text { Expense to Sales }=\frac{\text { Total Expense }}{\text { Sales }}
$$

\section{Efektivitas Pemasaran}

Menurut (Umar, 2003, p. 73) menyatakan bahwa efektivitas merupakan kemampuan suatu perusahaan dalam memilih tujuan yang tepat. Dimana pemasaran yang dilakukan suatu perusahaan dapat dikatakan efektif, jika pemasaran yang dilakukan perusahaan sesuai dengan yang perusahaan rencanakan. Oleh karena itu, efektivitas pemasaran merupakan sejauh mana suatu perusahaan dapat mencapai target yang telah ditetapkan sebelumnya (Rokhlinasari \& Deyanti, 2016). Oleh karena itu, efektivitas pemasaran merupakan sejauh mana suatu perusahaan dapat mencapai target yang telah ditetapkan sebelumnya (Rokhlinasari \& Deyanti, 2016). Semakin efektif kegiatan yang dilakukan oleh suatu perusahaan, maka akan semakin besar output yang dihasilkan oleh suatu perusahaan untuk mencapai tujuannya (Drucker dan Collins, 2017). Efektivitas pemasaran mencerminkan pencarian perusahaan akan bauran pemasaran yang lebih produktif (Kotler, 2003, p. 75). Efektivitas pemasaran diproksikan dengan Total Assets Turnover. Maka rumus dari TATO sebagai berikut:

$$
\text { Total Asset Turnover }=\frac{\text { Sales }}{\text { Total Asset }}
$$

\section{Leverage Keuangan}

Menurut Ross, et al (2016) menyatakan bahwa Leverage keuangan adalah suatu ukuran ketergantungan perusahaan atas penggunaan utang. Leverage keuangan adalah rasio yang dapat menunjukan bagaimana pemilik berusaha agar dapat memperbesar keuangan dengan cara mengeluarkan modal hutang (Sinha, 2012:108). Dengan alasan jika perusahaan menggunakan leverage keuangan merupakan leverage yang mewajibkan suatu perusahaan untuk mengeluarkan beban tetap yang berupa bunga kepada investor dan apabila laba operasi sebagai presentase terhadap aset melebihi tingkat bunga atas hutang, maka perusahaan dapat menggunakannya untuk membeli aset, membayar bunga atas hutang dan mendapatkan sisa bonus bagi pemegang saham. (Brigham \& Joel, 2013). Leverage keuangan diproksikan dengan Debt to Equity Ratio, dimana DER dapat mengetahui seberapa besar modal yang akan dibiayai oleh hutang. Debt to Equity Ratio (DER) merupakan rasio yang menunjukan perbandingan antara hutang terhadap modal (Soedjatmiko, Abdullah, \& Rifani, 2017). Debt to Equity Ratio (DER) adalah suatu rasio utang yang digunakan untuk mengukur seberapa hutang terhadap modal (Ramadhani, et al, 2018). Debt to Equity Ratio (DER) merupakan suatu rasio yang dapat menunjukan presentase dana yang disediakan oleh para pemegang saham kepada pemberi pinjaman pada suatu perusahaan (Darsono, 2005, dalam Lim, dkk, 2015). Debt to Equity Ratio (DER) yang semakin tinggi akan membuat laba yang diperoleh suatu perusahaan semakin besar. Maka rumus dari DER sebagai berikut:

$$
\text { Debt to Equity Ratio }=\frac{\text { Total Debt }}{\text { Total Equity }}
$$

\section{METODOLOGI}

Teknik yang digunakan dalam penelitian ini adalah Teknik analisis linear berganda. Obyek penelitian ini adalah Return on Equity, Efisiensi Operasional, Efektivitas Pemasaran, dan Leverage Keuangan. Populasi dalam penelitian ini yaitu perusahaan sub sektor ritel yang terdaftar di BEI periode 2016-2020. Metode yang digunakan adalah sensus, sehingga tidak 
menggunakan sampel dalam penelitian ini. Penelitian ini mengumpulkan data panel yang merupakan gabungan antara time series dan cross section dari populasi dan periode yang ditetapkan. Data yang dikumpulkan dalam penelitian ini adalah data sekunder yang diperoleh melalui website resmi BEI www.idx.co.id dan website resmi dari masing-masing perusahaan. Terdapat beberapa pengujian dalam penelitian ini yaitu Statistik Deskriptif, Uji Multikolinearitas, Uji Chow, Uji Hausman, Uji Lagrange Multiplier, Uji T, Uji F, dan Uji Koefisien Determinan.

\section{HASIL ANALISIS DATA}

\section{Statistik Deskriptif}

Penelitian ini menggunakan analisis statistik deskriptif, karena bertujuan untuk mendeskripsikan data dari masing-masing variabel dalam penelitian (Ghozali I. , 2011, p. 19). Statistik deskriptif dapat dilihat melalui pengukuran mean (nilai rata-rata), median, nilai minimum dan maksimum, varian, sum, jumlah observasi, dan standar deviasi dari tiap variabel penelitian. Hal ini dilakukan agar data yang digunakan akan lebih jelas serta lebih mudah dipahami.

Tabel 2. Hasil Statistik Deskriptif

\begin{tabular}{|c|c|c|c|c|}
\hline & ROE & Efisiensi Operasional & Efektivitas Pemasaran & Leverage Keuangan \\
\hline Mean & -2.198118 & 99.03812 & 2.372706 & 2.354471 \\
\hline Median & 7.680000 & 99.01000 & 1.850000 & 1.520000 \\
\hline Maximum & 108.8600 & 153.5800 & 18.03000 & 23.42000 \\
\hline Minimum & -219.4000 & 79.59000 & 0.290000 & 0.090000 \\
\hline Std. Dev. & 46.19590 & 8.671477 & 2.314172 & 3.177938 \\
\hline Skewness & -2.152915 & 2.772632 & 4.660664 & 3.960215 \\
\hline Kurtosis & 10.10907 & 20.23120 & 28.86480 & 24.52790 \\
\hline Jarque-Bera & 244.6549 & 1160.477 & 2677.057 & 1863.567 \\
\hline Probability & 0.000000 & 0.000000 & 0.000000 & 0.000000 \\
\hline Sum & -186.8400 & 8418.240 & 201.6800 & 200.1300 \\
\hline Sum Sq. Dev. & 179261.1 & 6316.339 & 449.8531 & 848.3405 \\
\hline Observations & 85 & 85 & 85 & 85 \\
\hline
\end{tabular}

Selanjutnya dilakukan Uji Chow memiliki nilai probabilitas sebesar 0.0000 , Uji Hausman memiliki nilai nilai probabilitas sebesar 0.6067, dan Uji Lagrange Multiplier memiliki nilai probabilitas sebesar 0.0000. Sehingga Random Effect Model merupakan model yang paling tepat digunakan dalam penelitian ini.

\section{Uji Regresi Linear Berganda}

Regresi data panel merupakan suatu kumpulan data dimana perilaku unit cross-sectional (seperti individu, perusahaan, negara, dsb) diamati sepanjang waktu yang berulang-ulang atau time series (Ghozali I. , 2017, p. 195). 
Tabel 3. Hasil Regresi Linear Berganda

\begin{tabular}{crrrr}
\hline \hline Variable & Coefficient & Std. Error & t-Statistic & Prob. \\
\hline \hline C & 197.3161 & 30.65860 & 6.435912 & 0.0000 \\
Efisiensi Operasional & -1.867001 & 0.304215 & -6.137113 & 0.0000 \\
Efektivitas Pemasaran & 3.658656 & 1.292575 & 2.830517 & 0.0059 \\
Leverage Keuangan & -9.892160 & 0.889106 & -11.12596 & 0.0000 \\
\hline \hline
\end{tabular}

Sumber: Data diolah menggunakan E-views 11

\section{DISKUSI}

Setelah dilakukan pengujian pada Tabel3, maka menujukan bahwa Variabel Efisiensi Operasional berpengaruh negatif dan signifikan terhadap ROE. Hasil penelitian ini sejalan dengan penelitian Growe, dkk (2014) yang menyatakan bahwa Expense to Sales berpengaruh negatif dan signifikan terhadap Return on Equity. Artinya semakin kecil perusahaan mengeluarkan biaya-biaya operasional, maka laba yang diperoleh perusahaan akan semakin besar.

Variabel Efektivitas Pemasaran berpengaruh positif dan signifikan terhadap ROE. Hasil penelitian ini sejalan dengan penelitian yang dilakukan oleh (Gunarta \& Abdi, 2019) dan Kartikaningsih (2013) yang menyatakan bahwa Total Asset Turnover berpengaruh positif dan signifikan terhadap Return on Equity. Artinya tingginya tingkat perputaran aset menunjukan bahwa perusahaan dapat mengelola asetnya secara efisien, maka akan berpengaruh pada peningkatan penjualan yang akan meningkatkan laba perusahaan.

Variabel Leverage Keuangan berpengaruh negative dan signifikan terhadap ROE. Hasil penelitian ini sejalan dengan penelitian yang dilakukan oleh Soedjatmiko, dkk (2017) yang menyatakan bahwa Leverage Keuangan berpengaruh terhadap Return on Equity. Artinya Penggunaan DER bagi kegiatan operasional perusahaan dapat memberikan keuntungan apabila laba yang dihasilkan optimal, karena semakin besar hutang yang digunakan akan semakin tinggi resiko untuk melunasi kewajibannya.

\section{KESIMPULAN}

Berdasarkan dari hasil pengolahan data dan pembahasan yang telah dilakukan, maka kesimpulan dari penelitian ini adalah sebagai berikut:

Efisiensi Operasional berpengaruh negatif dan signifikan terhadap Kinerja Keuangan Perusahaan Publik Bisnis Ritel yang terdaftar di Bursa Efek Indonesia pada periode 2016 2020.

Efektivitas Pemasaran berpengaruh positif dan signifikan terhadap Kinerja Keuangan Perusahaan Publik Bisnis Ritel yang terdaftar di Bursa Efek Indonesia pada periode 2016 2020.

Leverage Keuangan berpengaruh negatif dan signifikan terhadap Kinerja Keuangan Perusahaan Publik Bisnis Ritel yang terdaftar di Bursa Efek Indonesia pada periode 2016 2020.

Saran. Berdasarkan dari hasil yang telah diperoleh dalam penelitian ini serta kesimpulan diatas, maka saran yang dapat diberikan yaitu: 
Bagi perusahaan disarankan untuk memperhatikan Efisiensi Operasional dan Leverage Keuangan dengan meminimalkan biaya - biaya operasional sesuai dengan kebutuhan perusahaan agar dapat meningkatkan Return on Equity perusahaan, karena Efisiensi Operasional berpengaruh negatif dan signifikan terhadap Kinerja Keuangan.

Bagi perusahaan disarankan untuk memperhatikan Efektivitas Pemasaran dengan meningkatkan penggunaan aset yang dimiliki secara efisien yang berdampak pada tingkat pengembalian dana yang dapat diperoleh dengan cepat sehingga dapat meningkatkan Return on Equity perusahaan, karena Efektivitas Pemasaran berpengaruh positif dan signifikan terhadap Kinerja Keuangan.

\section{DAFTAR PUSTAKA}

Brigham, E. F., \& Ehrhardt, M. C. (2017). Financial Management: Theory \& Practice. Cengage Learning.

Brigham, F. E., \& Joel, F. H. (2013). Dasar-dasar Manajemen Keuangan. Jakarta: Salemba Empat.

Dewa, A. P. (2015). Analisis Kinerja Keuangan PT. Indofood Sukses Makmur Tbk di Bursa Efek Indonesia. Jurnal Ilmu dan Riset Manajemen, 4.

Dewi, M. (2018). Analisis Kinerja Keuangan Perusahaan dengan Menggunakan Du Pont System pada PT. Indosat, Tbk. Jurnal Penelitian Ekonomi Akuntansi, 2(2), 117-126.

Fahmi, I. (2011). Analisis Kinerja keuangan. Bandung: Penerbit Alfabeta.

Ghozali, I. (2011). Aplikasi Analisis Multivariate dengan Progam SPSS. Semarang: Badan Penerbit Universitas Diponegoro.

Ghozali, I. (2017). Aplikasi Analisis Multivariate dan Ekonometrika dengan Eviews. Semarang: BPFE Universitas Diponegoro.

Gunarta, W. S., \& Abdi, M. (2019). Profitabilitas, Manajemen Aset, Dan Leverage Sebagai Prediktor. Jurnal Manajerial dan Kewirausahaan, 1(3), 593-599.

Herry. (2015). Analisis Laporan Keuangan : Pendekatan Rasio Keuangan. Yogyakarta: CAPS (Center for Academic Publishing Service).

Horne, J. V., \& Wachowicz, Jr, J. (2008). Fundamentals of Financial Management.

Junaidi , L. D. (2018). Pengaruh Efisiensi Operasional Dengan Kinerja Profitabilitas Pada Sektor Manufaktur. Jurnal Warta.

Kariyoto. (2017). Analisa Laporan Keuangan. Malang: Universitas Brawijaya Press.

Kotler, P. (2003). Manajemen Pemasaran. (11, Ed.) Jakarta: Indeks kelompok Gramedia.

Kusmayadi. (2008). Cara Memilih dan Mengolah Makanan Untuk Perbaikan Gizi Masyarakat. Retrieved Januari 5, 2013, from https ://database.deptan.go.id

Nurviani. (2013). Perpres Ritel VS Persaingan Usaha.

Prianto, E., \& Amboningtyas, D. (2017). Analisis Du Pont System Untuk Menilai Kinerja Keuangan Perusahaan (Studi Kasus Pada PT Mayora Indah Tbk, PT. Delta Djakarta Tbk, dan PT. Indofood Sukses Makmur Tbk Periode Tahun 2010-2015). 
Rokhlinasari, S., \& Deyanti. (2016). Efektivitas Pemasaran Hijabstory Cabang. Retrieved from http://www.Scholar.google.co.id

Rudianto. (2013). Akuntansi Manajemen Informasi untuk Pengambilan Keputusan Strategis. Jakarta: Erlangga.

Sinha, G. (2012). Financial Statement Analysis. India: Mohan Makhijani.

Soedjatmiko, Abdullah, H., \& Rifani, A. (2017). Pengaruh Total Assets Turnover dan Financial Leverage Terhadap Return on Equity Pada Perusahaan Perdagangan yang Listing di Bursa Efek Indonesia. Dinamika Ekonomi Jurnal Ekonomi dan Bisnis, 10(1).

Sucipto. (2003). Penilaian Kinerja Keuangan. Universitas Sumatra Utara.

Sugiono, A., \& Untung, E. (2008). Panduan Praktis Dasar Analisa Laporan Keuangan. Jakarta: Grasindo.

Tarmizi, R., \& Marlim, M. (2016, September). Analisis Du Pont System dalam mengukur kinerja keuangan perusahaan. Jurnal Akuntansi dan Keuangan, 7(2), 211-233.

Umar, H. (2003). Business an Introduction. Jakarta: Gramedia Pustaka Utama.

Wahyudiono, B. (2014). Mudah Membaca Laporan Keuangan. Jakarta: Raih Asa Sukses.

Wahyuni, S. F. (2017). Peran Kepemilikan Institusional dalam Memoderasi Pengaruh Current Ratio, Debt To Equity Ratio, Total Asset Turnover dan Inventory Turnover Terhadap Return on Equity di Bursa Efek Indonesia.

Yohanes, \& Abdi, M. (2020). Pengaruh Kinerja Keuangan Terhadap Return Saham Perusahaan Food And. Jurnal Manajerial dan Kewirausahaan, 2(2), 351-360. 